\title{
Telomerase is regulated by protein kinase $C-\zeta$ in human nasopharyngeal cancer cells
}

\author{
Cheng-Chou YU, Shi-Ching LO and Tzu-Chien V. WANG ${ }^{1}$ \\ Department of Molecular and Cellular Biology, Chang Gung University, Kwei-San, Tao-Yuan 333, Taiwan
}

Telomerase, a specialized ribonucleoprotein reverse transcriptase that directs the synthesis of telomeric DNA, is repressed in normal human somatic cells, but is activated in most cancers. Little is known concerning how telomerase activity is activated and maintained in cancer cells. We have shown previously that inhibition of protein kinase $\mathrm{C}$ (PKC) decreases the telomerase activity of human nasopharyngeal carcinoma (NPC) cells. Here, we provide evidence that the decrease of telomerase activity by $\mathrm{PKC}$ inhibition is not mediated by transcriptional down-regulation of hTERT, the catalytic protein of human telomerase. In vitro phosphorylation studies revealed that exogenous addition of PKC- $\alpha,-\beta \mathrm{I},-\delta$ or $-\zeta$ led to restoration of telomerase activity in the crude extracts of PKC-inhibited NPC cells. However, depletion of PKC- $\alpha$ and $-\beta$ I in vivo had no detectable effect on the telomerase activity of NPC cells. Using antisense oligonucleotides against individual PKC isotypes, we observed that telomerase activity was inhibited only by the antisense oligonucleotide against PKC $-\zeta$ but not by those against PKC $-\alpha,-\beta$ I or $-\delta$. Taken together, these data demonstrate that PKC participates in the regulation of telomerase activity by direct or indirect phosphorylation of telomerase proteins, and that $\mathrm{PKC}-\zeta$ is the PKC isotype that functions in vivo in the NPC cells.

Key words: antisense PKC, hTERT, protein phosphorylation.

\section{INTRODUCTION}

Telomerase is a ribonucleoprotein reverse transcriptase that directs the synthesis of telomeric repeats at chromosome ends [1]. Normal human somatic cells express low or undetectable telomerase activities and are mortal. In contrast, moderate or high telomerase activity is present in the majority of immortal and cancer cells [2,3]. Ectopic expression of telomerase activity has been shown to extend the lifespan of several normal human cell types [4-7]. Ectopic expression of the telomerase catalytic subunit (the reverse transcriptase subunit of human telomerase, hTERT) in combination with two other oncogenes (the simian virus 40 large-T oncoprotein and oncogenic allele of $\mathrm{H}$-ras) has been shown to be sufficient to convert normal human epithelial and fibroblast cells into tumour cells [8]. Together these observations support an important role for telomerase in cellular immortalization and carcinogenesis.

The minimal catalytic core of human telomerase consists of an RNA component (hTER) and of a catalytic protein subunit (hTERT) with reverse transcriptase activity [9-14]. Additional telomerase-associated proteins (hTEP1, dyskerin, p23 and Hsp90) have been identified [15-18], yet their biochemical functions remain obscure. Studies on the correlation between telomerase activity and the expression of hTER, hTEP1, and hTERT have indicated that telomerase activity is strongly correlated with the abundance of hTERT mRNA [10,11]. The abundance of mRNA for hTEP1 and hTER does not correlate with telomerase activity $[15,16,19]$. Together with the result that ectopic expression of hTERT in somatic cells is sufficient to restore telomerase activity [4-7,12,20], these observations demonstrate that hTERT is the key regulator of enzyme activity.
Little is known concerning how telomerase activity is regulated in human cells. The promoter region of the hTERT gene has been characterized [21-23]. Sequence analysis has revealed that the hTERT promoter contains hormone-response elements and binding sites for several transcription factors, including c-Myc, Sp1 and others [21-23], implying that hTERT expression may be regulated by multiple factors. Overproduction of c-Myc has been shown to induce expression of hTERT and of telomerase activity [24-26], whereas inhibition of c-Myc inhibits telomerase activity in leukaemic cell lines [27]. Up-regulation of telomerase activity in T-lymphocytes during activation has been shown to correlate with the induction of hTERT expression [28], and is known to require protein kinase $\mathrm{C}$ (PKC)-dependent activity $[29,30]$. Similarly, down-regulation of telomerase activity in differentiated pro-myelocytic HL-60 cells has been shown to correlate with down-regulation of hTERT expression [11,31]. Therefore, transcriptional regulation of hTERT expression appears to be the primary method of controlling telomerase. In addition to transcriptional regulation, reversible phosphorylation of telomerase proteins has been shown to control telomerase activity [32-34]. PKC- $\alpha$ is reported to be responsible for phosphorylating telomerase proteins in breast cancer cells [33].

We have shown previously that the telomerase activity of human nasopharyngeal carcinoma (NPC) cells is inhibited by treatment with inhibitors of $\mathrm{PKC}$, indicating that $\mathrm{PKC}$ is involved in the control of telomerase activity in these cells [35]. As yet, it is not known which PKC isotype is involved and what the mechanism of regulation by PKC in NPC cells is. In this study, we present evidence that $\mathrm{PKC}$ participates in the regulation of telomerase activity by direct or indirect phosphorylation of telomerase proteins, and that $\mathrm{PKC}-\zeta$ is the $\mathrm{PKC}$ isotype that functions in the NPC cells in vivo.

Abbreviations used: NPC, nasopharyngeal carcinoma; PKC, protein kinase C; BIM, bisindolylmaleimide I; hTERT, reverse transcriptase subunit of human telomerase; TRAP, telomeric-repeat-amplification protocol.

1 To whom correspondence should be addressed (e-mail tcrwg@mail.cgu.edu.tw). 


\section{MATERIALS AND METHODS}

\section{Chemicals, enzymes, antibodies and oligonucleotides}

Dulbecco's modified Eagle's medium, fetal bovine serum, LipofectAMINE $^{\text {TM }}$ 2000, Superscript II reverse transcriptase, TRIzol reagent and antibiotics were from Gibco-BRL. Bisindolylmaleimide I (BIM), RNase inhibitor and PMA were purchased from Calbiochem. PKC- $\alpha,-\beta \mathrm{I},-\delta$ and $-\zeta$ were from BioMol Research Lab. Taq DNA polymerase was from Viogene (Taipei, Taiwan). Antibodies against individual PKC isotypes and secondary antibodies were from Santa Cruz Biotechnology. Anti-digoxigenin antibody conjugated with horseradish peroxidase was from Boehringer Mannheim. The sequences and sources of oligonucleotides TS, CX, biotinylated TS and digoxigeninated CX have been described previously [36]. Other oligonucleotides used are listed in Table 1 and were from Genasia Scientifics (Taipei, Taiwan). The antisense oligonucleotides against $\mathrm{PKC}-\alpha,-\beta \mathrm{I},-\delta$ and $-\zeta$ were synthesized as phosphorothiotide derivatives and tagged at the $5^{\prime}$ ends with FITC. Gelelectrophoresis reagents were from BioRad. All other chemicals were from Sigma.

\section{Cell culture}

NPC-derived cell line NPC-076 was cultured routinely in Dulbecco's modified Eagle's medium supplemented with $10 \%$ fetal bovine serum, $2 \mathrm{mM}$ L-glutamine, 100 units $/ \mathrm{ml}$ penicillin, 100 units $/ \mathrm{ml}$ streptomycin and $0.25 \mu \mathrm{g} / \mathrm{ml}$ amphotericin B. Cells were grown at $37^{\circ} \mathrm{C}$ in a humidified incubator containing $5 \%$ $\mathrm{CO}_{2}$.

\section{Telomerase activity assay}

Cell extracts were obtained as described in [35]. Telomerase activity was assayed by conventional telomeric-repeatamplification protocol (TRAP) [2] and by a PCR-based enzyme immunoassay as described previously [36].

\section{Determination of mRNA expression of hTERT by reverse transcriptase PCR}

Total RNA was extracted by TRIzol isolation reagent (GibcoBRL) following the manufacturer's instructions. The primers used were: LT5 and LT6 for hTERT [11] and K136 and K137 for GAPDH [11] (see Table 1). The conditions for reverse transcriptase PCR were predetermined with serial dilutions of total RNA isolated from the untreated NPC-076 cells such that the amount of RNA used in the reaction was in the linear range

Table 1 Sequences of the oligonucleotides used

\begin{tabular}{ll}
\hline \multicolumn{1}{l}{ Oligonucleotide } & Sequence \\
\hline LT5 & 5'-CGGAAGAGTGTCTGGAGCAA-3' \\
LT6 & 5'-GGATGAAGCGGAGTCTGGA-3' \\
K136 & 5'-CTCAGACACCATGGGGAAGTGA-3' \\
K137 & 5'-ATGATCTTGAGGCTGTTGTCATA-3' $^{\prime}$ \\
Antisense-PKC- $\alpha$ & 5'-ACGTCAGCCATGGTCCC-3' $^{\prime}$ \\
Antisense-PKC- $\beta$ 1 & 5'-GGGTCAGCCATCTTGCG-3' $^{\prime}$ \\
Antisense-PKC- $\delta$ & $5^{\prime}$-GAACGGCGCCATGGTGGG-3' \\
Antisense-PKC- $\zeta$ & $5^{\prime}$-GCTCCCTTCCATCTTGGG-3' \\
Sense-PKC- $\zeta$ & $5^{\prime}$-CCCAAGATGGAAGGGAGC-3'
\end{tabular}

(C) 2001 Biochemical Society
A

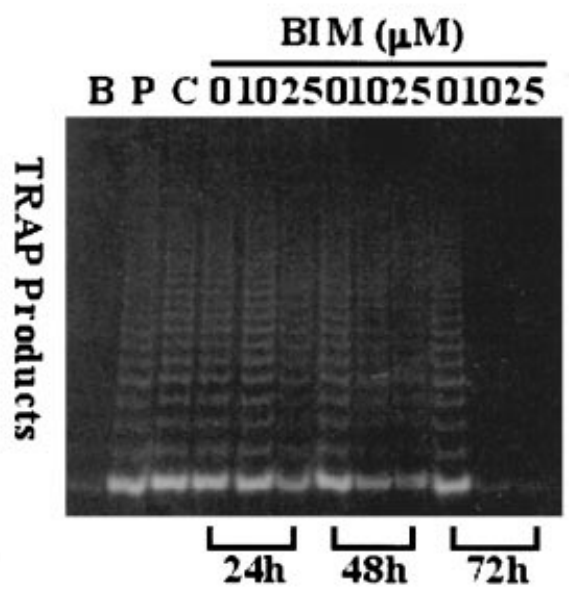

B

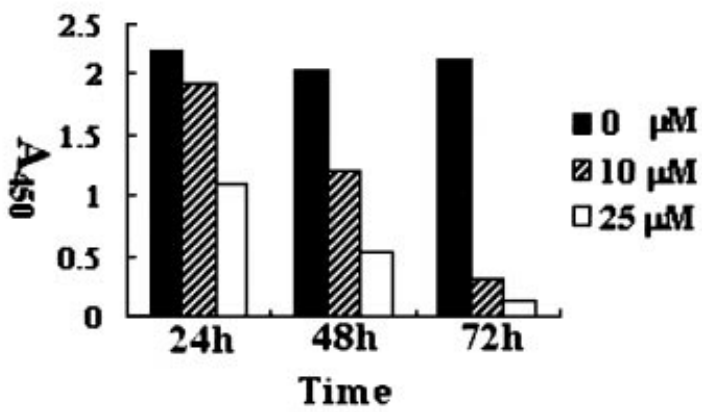

Figure 1 Down-regulation of telomerase activity in NPC-076 cells treated with the PKC inhibitor BIM

NPC-076 cells were cultured in the absence or presence of BIM at 10 or $25 \mu \mathrm{M}$ for the indicated times. Telomerase activity was assayed with $0.5 \mu \mathrm{g}$ of cell protein extract using the TRAP method (A) and a PCR-based enzyme immunoassay (B). (A) Lane B, control reaction without cell extract; lane $\mathrm{P}$, control reaction using cell extract from telomerase-positive $\mathrm{HL}-60$ cells; lane $C$, reaction with cell extract obtained from NPC-076 cells prior to treatment. Results shown in $(\mathbf{A})$ are from one of two similar experiments and results shown in $(\mathbf{B})$ are means from two experiments.

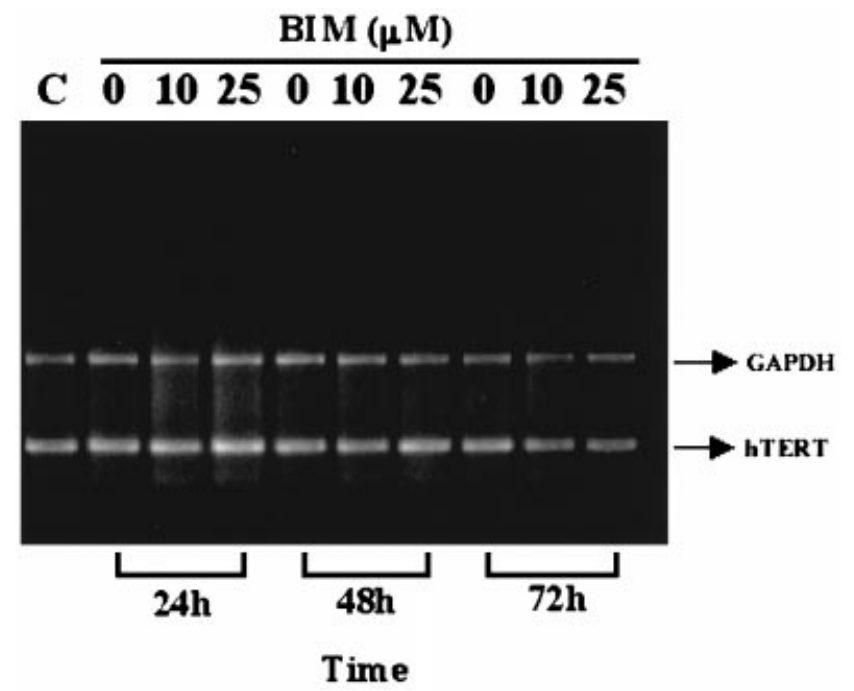

Figure 2 Expression of hTERT mRNA in BIM-treated NPC-076 cells

NPC-076 cells were cultured and treated with BIM as described for Figure 1. The expression of hTERT mRNA was monitored by reverse transcriptase PCR as described in the Materials and methods section. The expression of GAPDH mRNA served as an internal control. Results are from one of three similar experiments. 
A

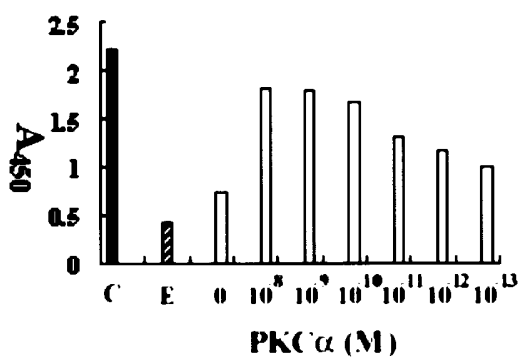

(

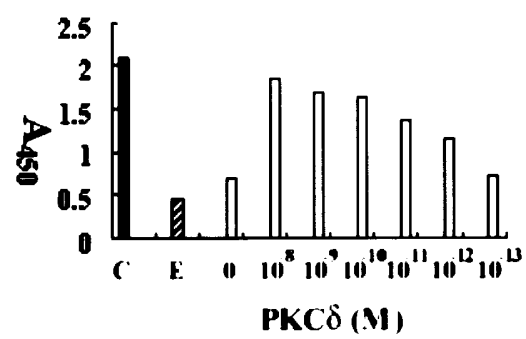

B

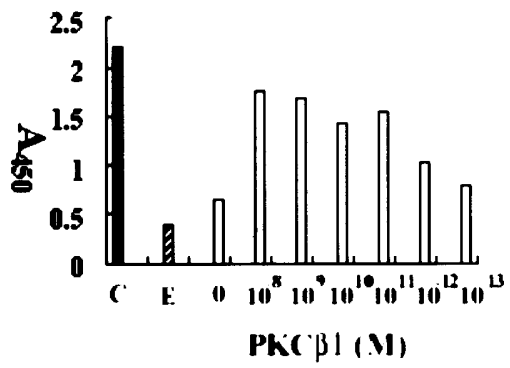

D

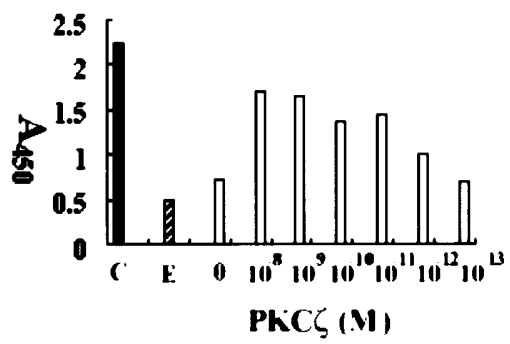

Figure 3 Reactivation of telomerase activity by in vitro phosphorylation of PKC-inhibited cell extract

Cell extracts were obtained from NPC-076 cells treated with $10 \mu \mathrm{M} \mathrm{BIM}$ for 3 days and were phosophorylated in vitro by exogenous addition of PKC- $\alpha(\mathbf{A}),-\beta \mid(\mathbf{B}),-\delta(\mathbf{C})$ or $-\zeta(\mathbf{D})$ as described in the Materials and methods section. Aliquots of phosphorylated cell extract $(0.5 \mu \mathrm{g})$ were assayed for telomerase activity using PCR-based enzyme immunoassay. C is a control using NPC076 cell extract not treated with BIM. E means reaction with BIM-treated cell extract. Results are the means from two experiments.

of the assay. In brief, reverse transcription was performed at $42{ }^{\circ} \mathrm{C}$ for $1 \mathrm{~h}$ in $20 \mu \mathrm{l}$ of buffer containing $50 \mathrm{mM}$ Tris $(\mathrm{pH} 8.3)$, $75 \mathrm{mM} \mathrm{KCl}, 3 \mathrm{mM} \mathrm{MgCl}, 2 \mu \mathrm{g}$ of total RNA, $0.5 \mu \mathrm{g}$ of oligodT, 10 units of RNasin, 4 units of Superscript II and dNTPs at $1 \mathrm{mM}$. Reverse transcriptase reaction products $(2 \mu \mathrm{l})$ were added to $20 \mu \mathrm{l}$ of PCR mixture containing $20 \mathrm{mM}$ Tris (pH 8.3), $50 \mathrm{mM}$ $\mathrm{KCl}, 0.25 \mathrm{mM}$ dNTPs, $0.1 \mathrm{mg} / \mathrm{ml} \mathrm{BSA}, 0.5 \mathrm{mM} \mathrm{MgCl}_{2}, 10 \mathrm{pmol}$ of each primer and 2 units of Taq DNA polymerase. PCR amplification for cDNA of hTERT and GAPDH was carried out with 31 cycles of denaturation at $94{ }^{\circ} \mathrm{C}$ for $30 \mathrm{~s}$, annealing at $55^{\circ} \mathrm{C}$ for $30 \mathrm{~s}$, and extension at $72^{\circ} \mathrm{C}$ for $1 \mathrm{~min}$. The PCR products were resolved by electrophoresis on a $2.5 \%$ agarose gel and analysed as described in [35].

\section{Western-blot analysis of PKC isotypes}

Western-blot analysis was performed as follows. Protein extract $(20 \mu \mathrm{g})$ was added to a sample buffer containing $25 \mathrm{mM}$ Tris/ $\mathrm{HCl}$ (pH 6.8), $5 \%$ glycerol, $1 \%$ SDS, $0.1 \mathrm{M}$ dithiothreitol and $0.1 \%$ Bromophenol Blue, and boiled for $5 \mathrm{~min}$. After electrophoresis in an SDS/polyacrylamide gel $(8 \%)$, proteins were transferred to a PVDF membrane in a wet transfer system (Hoefer Pharmacia Biotech) at $0.8 \mathrm{~mA} / \mathrm{cm}^{2}$ for $2 \mathrm{~h}$ using a buffer containing $10 \mathrm{mM}$ Caps and $20 \%$ methanol. The membrane was then blocked by immersing in TTBS buffer $[10 \mathrm{mM}$ Tris $/ \mathrm{HCl}$ (pH 8.3), $0.05 \%$ Tween- 20 and $150 \mathrm{mM} \mathrm{NaCl}$ containing $5 \%$ non-fat dried milk at $4{ }^{\circ} \mathrm{C}$ overnight. After decanting the blocking buffer, membrane was incubated with anti-PKC antibody in TTBS buffer for $2 \mathrm{~h}$ at room temperature. After washing four times with TTBS, membrane was incubated with horseradish peroxidase in TTBS for $1 \mathrm{~h}$ at room temperature. After washing, membrane was submerged in ECL developing solution (Amersham Pharmacia Biotech, Little Chalfont, Bucks., U.K.) and autoradiographed. The level of actin was used as an internal control to determine the relative expression of PKC isotypes in different samples.

\section{Transfection of oligonucleotides}

Antisense oligonucleotides against $\mathrm{PKC}-\alpha,-\beta \mathrm{I},-\delta$ or $-\zeta$ were transfected into NPC-076 cells using LipofectAMINE ${ }^{\text {TM }} 2000$ following the supplier's instructions.

\section{Protein phosphorylation in vitro}

The conditions for protein phosphorylation followed those described by $\mathrm{Li}$ et al. [33]. For PKC-mediated protein phosphorylation, $5 \mu \mathrm{g}$ of protein extract was phosphorylated by exogenous addition of individual $\mathrm{PKC}$ isotypes to a $20 \mu 1$ reaction mixture containing $30 \mathrm{mM}$ Tris $/ \mathrm{HCl}$ (pH 7.4), $1 \mathrm{mM} \mathrm{MgCl}_{2}$, $1 \mathrm{mM}$ EGTA, $0.2 \mathrm{mM} \quad \mathrm{CaCl}_{2}, \quad 10 \mu \mathrm{M} \quad$ PMA, $40 \mu \mathrm{g} / \mathrm{ml}$ phosphatidylserine and $40 \mu \mathrm{M}$ ATP. After incubation at $30{ }^{\circ} \mathrm{C}$ for $15 \mathrm{~min}$, aliquots of phosphorylated cell extract were assayed for telomerase activity as described above.

\section{RESULTS AND DISCUSSION}

Inhibition of PKC activity has been shown to inhibit telomerase activity of NPC cells [35]. Since PKC can control telomerase activity by regulating the expression of telomerase genes and/or 


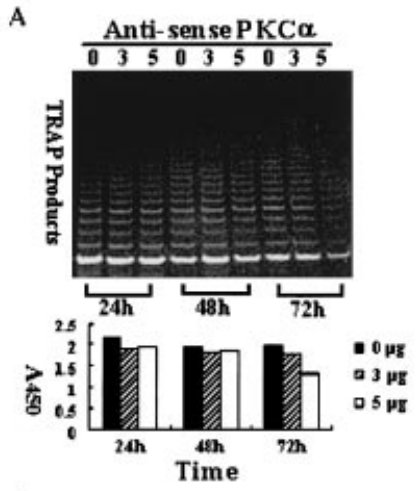

C

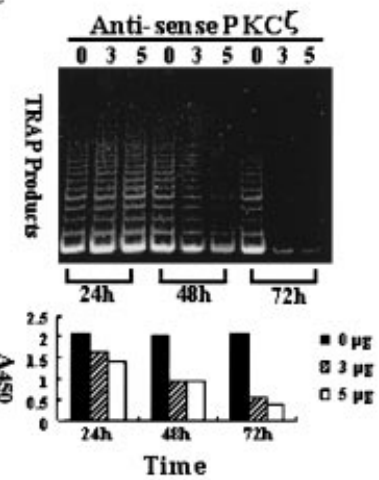

B

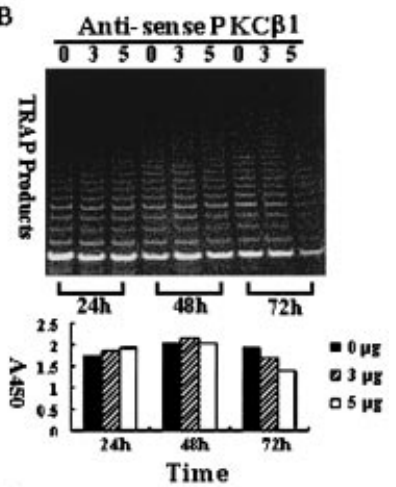

D

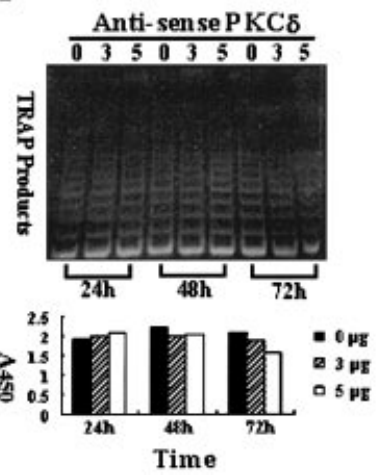

Figure 4 Effects of antisense oligonucleotides against PKC isotypes on the telomerase activity of NPC-076 cells

NPC-076 cells were transfected with $0-5 \mu \mathrm{g}$ of antisense PKC- $\alpha$ (A), PKC- $\beta$ | (B), PKC- $\zeta$ (C) or PKC- $\delta$ (D) oligonucleotide and cultured for the indicated times. Telomerase activity was assayed with $0.5 \mu \mathrm{g}$ of cell protein extract using the TRAP method and a PCR-based enzyme immunoassay. Results from the TRAP method are for one of two similar experiments. Results assayed by PCR-based enzyme immunoassay are the means from two experiments.

by phosphorylating telomerase proteins, the first question we addressed was whether the expression of the key telomerase regulator, hTERT, is suppressed by inhibiting PKC. NPC-076 cells were treated with BIM, an inhibitor of PKC, and the expression of hTERT mRNA and telomerase activity were followed. As shown in Figure 1, telomerase activity of NPC-076 cells was inhibited by BIM in a dose-dependent and timedependent manner, as observed before [35]. However, the expression hTERT mRNA was not inhibited at all (Figure 2). This result indicates that the inhibition of telomerase activity by BIM is not due to the suppression of hTERT expression.

Inhibition of telomerase activity by BIM without downregulating hTERT expression suggests that PKC may control telomerase activity by phosphorylating telomerase proteins in NPC cells. Accordingly, we postulate that the telomerase of BIM-treated cells is not phosphorylated and, therefore, lacks activity. Rephosphorylation of telomerase in BIM-treated cells should lead to the activation of telomerase activity. To test this postulate, cell extracts were prepared from NPC-076 cells that had been pretreated with $10 \mu \mathrm{g} / \mathrm{ml}$ BIM for 3 days. These cell extracts were phosphorylated in vitro by exogenous addition of PKC isotypes that were expressed in NPC-076 cells, and tested for the restoration of telomerase activity. As shown in Figure 3, phosphorylation of BIM-treated cell extracts by exogenous addition of any individual $\mathrm{PKC}, \alpha, \beta \mathrm{I}, \delta$ or $\zeta$, led to restoration of telomerase activity. Therefore, the inhibition of telomerase

Anti-sense PKC $(\mu \mathrm{g})$

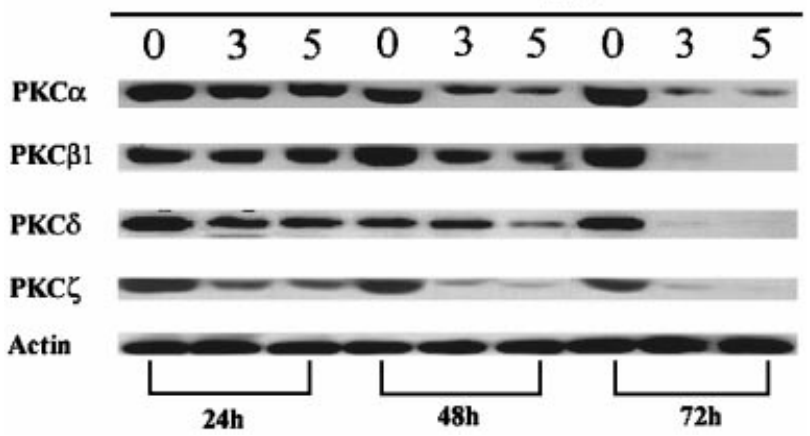

Figure 5 Levels of PKC isotypes in NPC-076 cells treated with antisense oligonucleotides against PKC isotypes

NPC-076 cells were transfected with $0-5 \mu \mathrm{g}$ of antisense PKC oligonucleotides and cultured for the indicated times. The levels of PKC isotypes were monitored by Western blotting as described in the Materials and methods section. The level of actin, which served as an internal control, was similar in all of the antisense-PKC-treated samples. The data shown in the Figure were from the experiment with antisense-PKC- $\zeta$.

activity observed in BIM-treated cells (Figure 1) is probably attributable to the lack of phosphorylation in the telomerase proteins.

Although any one of PKC- $\alpha,-\delta,-\epsilon$ or $-\zeta$ has been shown to be capable of restoring telomerase activity in protein phosphatase 2A-treated nuclear extracts of breast cancer cells in vitro, only $\mathrm{PKC}-\alpha$ is thought to be responsible for the in vivo phosphorylation of telomerase proteins [33]. Therefore, despite the fact that any one of $\mathrm{PKC}-\alpha,-\beta \mathrm{I},-\delta$ or $-\zeta$ can restore telomerase activity of $\mathrm{PKC}$-inhibited cell extracts in vitro (Figure 3), NPC cells may employ only one PKC isotype to control telomerase activity in vivo. An obvious question to be addressed is whether NPC-076 cells might employ PKC- $\alpha$ to control telomerase activity. An antisense oligonucleotide against PKC- $\alpha$ was used to specifically inhibit $\mathrm{PKC}-\alpha$, and was found to produce little or no inhibition of telomerase activity (Figure 4A). Under our experimental conditions, more than $75 \%$ of the cells were transfected effectively with the FITC-tagged oligonucleotides, as seen from microscopic examination of cells that display fluorescence. Western-blot analysis revealed that the level of PKC- $\alpha$ in the antisense-PKC- $\alpha$-treated cells was reduced to about $20 \%$ of the untreated control after 3 days (Figure 5). The lack of telomerase inhibition by antisense-PKC- $\alpha$, therefore, suggests that either PKC- $\alpha$ does not control telomerase activity in NPC cells or that the residual PKC- $\alpha$ in the treated cells is sufficient to control telomerase activity. To address this problem, we investigated the effect of depleting $\mathrm{PKC}-\alpha$ on the telomerase activity. NPC-076 cells were treated with 100-200 ng/ml PMA, an agent known to deplete $\mathrm{PKC}-\alpha$ and down-regulate $\mathrm{PKC}$ upon prolonged treatment [37], and the levels of telomerase activity and PKC isotypes were analysed. As shown in Figure 6, there was no detectable inhibition of telomerase activity during the entire treatment period. Western-blot analysis revealed that PKC- $\alpha$ and PKC- $\beta$ I were depleted rapidly from the cells treated with PMA and were not detectable after $24 \mathrm{~h}$ (Figure 7). PKC$\delta$ was also depleted from the cells, but at a much slower rate. In contrast, there was little change in the levels of PKC- $\zeta$ during the entire treatment period. Since PKC- $\alpha$ and PKC- $\beta$ I were depleted to undetectable levels in the PMA-treated cells, yet the telomerase activity was not inhibited at all, these results demonstrate that 
$\mathbf{A}$

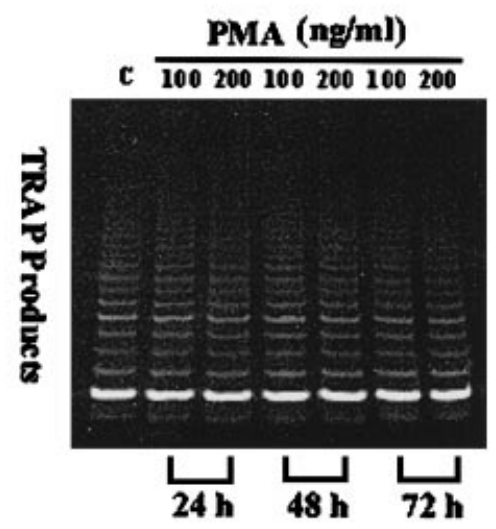

B

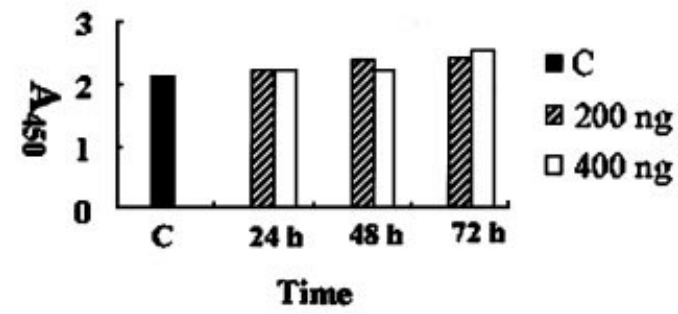

Figure 6 Effects of PMA on the telomerase activity of NPC-076 cells

NPC-076 cells were treated with 100 or $200 \mathrm{ng} / \mathrm{ml}$ PMA and cultured for the indicated times. Telomerase activity was assayed with $0.5 \mu \mathrm{g}$ of cell protein extract using the TRAP method (A) and a PCR-based enzyme immunoassay (B). Results from by the TRAP method are from one of three similar experiments. Results from the PCR-based enzyme immunoassay are the means from two experiments. $\mathrm{C}$ is the control from untreated cell extract.

PKC- $\alpha$ and PKC- $\beta$ I do not regulate the basal activity of telomerase in NPC-076 cells.

To determine whether PKC- $\delta$ or PKC- $\zeta$ might be involved in the control of telomerase activity and to confirm that PKC- $\beta \mathrm{I}$ does not control telomerase activity, NPC-076 cells were treated with antisense oligonucleotides against PKC- $\beta \mathrm{I}, \mathrm{PKC}-\delta$ or $\mathrm{PKC}-\zeta$, and the levels of PKC isotypes and telomerase activity were examined. Whereas the levels of the three PKC isotypes were greatly reduced by the antisense oligonucleotides (Figure 5), treatment of NPC-076 cells with antisense-PKC- $\beta$ I or antisensePKC- $\delta$ did not inhibit telomerase in the first 2 days and only slightly reduced telomerase activity by day 3 (Figures $4 \mathrm{~B}$ and 4D). In contrast, the telomerase activity of cells treated with antisense-PKC- $\zeta$ was inhibited significantly, beginning at day 2 , and was reduced to less than $25 \%$ of the untreated control after 3 days (Figure 4C). Transfection of sense PKC- $\zeta$ oligonucleotides produced no inhibition of telomerase activity (results not shown), and the results were similar to that produced by antisense-PKC$\alpha$, antisense-PKC- $\beta$ I or antisense-PKC- $\delta$. The specific inhibition of telomerase activity by antisense-PKC- $\zeta$ indicates that PKC- $\zeta$ controls telomerase activity in NPC cells. This conclusion is also consistent with the results shown for PMA-treated cells (Figures 6 and 7) in that the lack of PKC- $\zeta$ degradation was accompanied by a lack of telomerase inhibition.

Taken together, these results establish that PKC participates in the regulation of telomerase activity in NPC cells by direct or indirect phosphorylation of telomerase proteins and not by PKC-dependent signal transduction to regulate the expression of
A

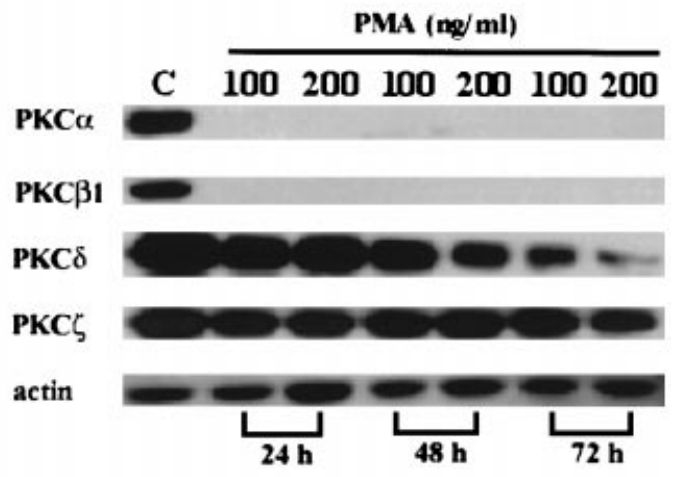

B

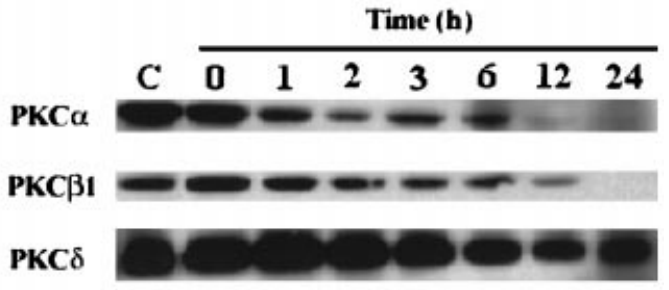

Figure 7 Levels of PKC isotypes in PMA-treated NPC-076 cells

(A) NPC-076 cells were treated with 100 or $200 \mathrm{ng} / \mathrm{ml}$ of PMA and cultured for the indicated times. The levels of PKC isotypes were monitored by Western blotting as described in the Materials and methods section. The level of actin served as an internal control. (B) Earlier kinetics of PKC-isotype depletion in NPC-076 cells treated with $100 \mathrm{ng} / \mathrm{ml}$ PMA. In both panels, $\mathrm{C}$ is a control from untreated cell extract.

the key telomerase component, hTERT. Of the four PKC isotypes expressed in NPC cells, we provide evidence that PKC- $\zeta$ is the $\mathrm{PKC}$ isotype that controls telomerase in vivo. Our findings are consistent with idea that reversible phosphorylation of telomerase proteins plays an important role in regulating telomerase activity in cancer cells $[32-34,38]$. However, our finding of a pivotal role of $\mathrm{PKC}-\zeta$ in the control of telomerase in vivo differs from that reported for PKC- $\alpha$ in human breast cancer cells [33]. This difference may be due to experimental methods and/or different types of cancer cells used. Evidence for a specific regulatory role of $\mathrm{PKC}-\alpha$ in human breast cancer cells is based on the association of $\mathrm{PKC}-\alpha$ with partially purified telomerase in the nuclei of such cells [33]. Our deduction for a regulatory role of PKC- $\zeta$, but not PKC- $\alpha$ or other PKC isotypes, is based on studies with antisense oligonucleotides against individual PKC isotypes and with a PKC-down-regulating agent, PMA (Figures 4-6). It is likely that the conclusions drawn from both studies are valid, the difference may merely reflect that different PKC isotypes are used in different types of cell to regulate telomerase.

This work is supported by Chang Gung Medical Research Grant CMRP 637, and National Science Council Research Grants NSC 89-2318-B182-002-M51 and NSC 89-2316-B182-004 of Taiwan.

\section{REFERENCES}

1 Blackburn, E. H. (1992) Telomerase. Annu. Rev. Biochem. 61, 113-129

2 Kim, N. W., Piatyszek, M. A., Prowse, K. R., Harley, C. B., West, M. D., Ho, P. L. C., Coveillo, G. M., Wright, W. E., Weinrich, S. L. and Shay, J. W. (1994) Specific association of human telomerase activity with immortal cell lines and cancer. Science 266, 2011-2015 
3 Shay, J. W. and Bacchetti, S. (1997) A survey of telomerase activity in human cancer. Eur. J. Cancer 33, 787-791

4 Counter, C. M., Meyerson, M., Eaton, E. N., Ellisen, L. W., Daddle, S. D., Haber, D. A. and Weinberg, R. A. (1998) Telomerase activity is restored in human cells by ectopic expression of hTERT(hEST2), the catalytic subunit of telomerase. Oncogene $\mathbf{1 6}$, 1217-1222

5 Bodnar, A. G., Ouellette, M., Frolkis, M., Holt, S. E., Chiu, D. P., Morin, G. B., Harley, C. B., Shay, J. W., Lichtsteiner, S. and Wright, W. E. (1998) Extension of life-span by introduction of telomerase into normal human cells. Science 279, 349-352

6 Varizi, H. and Benchimol, S. (1998) Reconstitution of telomerase activity in normal human cells leads to elongation of telomeres and extended replicative life span. Curr. Biol. 8, 279-282

7 Nakayama, J. I., Tahara, H., Tahara, E., Saito, M., Ito, K., Nakamura, H., Nakanishi, T., Tahara, E., Ide, T. and Ishikawa, F. (1998) Telomerase activation by hTRT in human normal fibroblasts and hepatocellular carcinomas. Nat. Genet. 18, 65-68

8 Hahn, W. C., Counter, C. M., Lundberg, A. S., Beijersbergen, R. L., Brooks, M. W. and Weinberg, R. A. (1999) Creation of human tumour cells with defined genetic elements. Nature (London) 400, 464-468

9 Feng, J., Funk, W. D., Wang, S. S., Weinrich, S. L., Avilion, A. A., Chiu, C. P., Adams, R. R., Chang, E., Allsopp, R. C. and Yu, J. et al. (1995) The RNA component of human telomerase. Science 269, 1236-1241

10 Meyerson, M., Counter, C. M., Eaton, E. N., Ellisen, L. W., Steiner, P., Dickinson Caddle, S., Ziaugra, L., Beijersbergen, R. L. and Davidoff, M. J. et al. (1997) hEST2, the putative human telomerase catalytic subunit gene, is upregulated in tumor cells and during immortalization. Cell 90, 785-795

11 Nakamura, T. M., Morin, G. B., Chapman, K. B., Weinrich, S. L., Andrews, W. H., Lingner, J., Harley, C. B. and Cech, T. R. (1997) Telomerase catalytic subunit homologs from fission yeast and human. Science 277, 955-959

12 Weinrich, S. L., Pruzan, R., Ma, L., Ouellette, M., Tesmer, V. M., Holt, E., Bodnar, A. G., Lichtsteiner, S., Kim, N. W. and Tragger, J. B. et al. (1997) Reconstitution of human telomerase with the template RNA component hTR and the catalytic protein subunit hTRT. Nat. Genet. 17, 498-502

13 Beattie, T. L., Zhou, W., Robinson, M. 0. and Harrington, L. (1998) Reconstitution of human telomerase activity in vitro. Curr. Biol. 8, 177-180

14 Nugent, C. I. and Lundblad, V. (1998) The telomerase reverse transcriptase: components and regulation. Genes Dev. 12, 1073-1085

15 Harrington, L., McPhail, T., McPhail, T., Mar, V., Zhou, W., Oulton, R., Bass, M. B., Arruda, I. and Robinson, M. 0. (1997) A mammalian telomerase-associated protein. Science 275, 973-977

16 Nakayama, J. I., Saito, M., Nakamura, H., Matsuura, A. and Ishikawa, F. (1997) TLPI: a gene encoding a protein component of mammalian telomerase is a novel member of WD repeats family. Cell $\mathbf{8 8}, 875-884$

17 Mitchell, J. R., Wood, E. and Collins, K. (1999) Functional requirement of p23 and Hsp90 in telomerase complexes. Nature (London) 402, 551-555

18 Holt, S. E., Aisner, D. L., Baur, J., Tesmer, V. M., Dy, M., Ouellette, M., Trager, J. B., Morin, G. B., Toft, D. O. and Shay, J. W. et al. (1999) A telomerase component is defective in the human disease dyskeratosis congenita. Genes Dev. 13, 817-826

19 Avilion, A. A., Piatyszek, M. A., Gupta, J., Shay, J. R., Bacchetti, S. and Greider, C. W. (1996) Human telomerase RNA and telomerase activity in immortal cell lines and tumor tissues. Cancer Res. 56, 645-650

20 Wen, J., Cong, Y.-S. and Bacchetti, S. (1998) Reconstitution of wild-type or mutant telomerase activity in telomerase-negative immortal human cells. Hum. Mol. Genet. 7, $1137-1141$

Received 15 November 2000/16 January 2001; accepted 8 February 2001
21 Cong, Y.-S., Wen, J. and Bacchetti, S. (1999) The human telomerase catalytic subunit hTERT: organization of the gene and characterization of the promoter. Hum. Mol. Genet. 8, 137-142

22 Horikawa, I., Cable, P. L., Afshari, C. and Barrett, J. C. (1999) Cloning and characterization of the promoter region of human telomerase reverse transcriptase gene. Cancer Res. 59, 826-830

23 Takakura, M., Kyo, S., Kanaya, T., Hirano, H., Takeda, J., Yutsudo, M. and Inoue, M. (1999) Cloning of human telomerase catalytic subunit (hTERT) gene promoter and identification of proximal core promoter sequences essential for transcriptional activation in immortalized and cancer cells. Cancer Res. 59, 551-557

24 Wang, J., Xie, L. Y., Allan, S., Beach, D. and Hannon, G. J. (1998) Myc activates telomerase. Genes Dev. 12, 1769-1774

25 Wu, K. J., Grandori, C., Amacker, M., Simmon-Vermot, N., Polack, A., Lingner, J. and Dalla-Favera, R. (1999) Direct activation of TERT transcription by c-MYC. Nature Genet. 21, 220-224

26 Greenberg, R. A., Lichtsteiner, S., Chin, L., Morin, G. B. and DePinho, R. A. (1999) Telomerase reverse transcriptase gene is a direct target of c-Myc but is not functionally equivalent in cellular transformation. Oncogene 18, 1219-1226

27 Fujimoto, K. and Takahashi, M. (1997) Telomerase activity in human leukemic cell lines is inhibited by antisense pentadecadeoxynucleotides targeted against c-myc mRNA. Biochem. Biophys. Res. Commun. 241, 775-781

28 Liu, K., Schoonmaker, M. M., Levine, B. L., June, C. H., Hodes, R. J. and Weng, N.-P. (1999) Constitutive and regulated expression of telomerase reverse transcriptase (hTERT) in human lymphocytes. Proc. Natl. Acad. Sci. U.S.A. 96, 5147-5152

29 Bodnar, A. G., Kim, N. W., Effros, R. B. and Chiu, C. P. (1996) Mechanism of telomerase induction during $T$ cell activation. Exp. Cell Res. 228, 58-64

30 Igarashi, H. and Sakaguchi, N. (1996) Telomerase activity is induced by the stimulation to antigen receptor in human peripheral lymphocytes. Biochem. Biophys. Res. Commun. 219, 649-655

31 Xu, D., Gruber, A., Bjorkholm, M., Peterson, C. and Pisa, P. (1999) Suppression of telomerase reverse transcriptase (hTERT) expression in differentiated HL-60 cells: regulatory mechanisms. Br. J. Cancer Res. 80, 1156-1161

32 Li, H., Zhao, L. L., Funder, J. W. and Liu, J.-P. (1997) Protein phosphatase 2A inhibits nuclear telomerase activity in human breast cancer cells. J. Biol. Chem. 272, 16729-16732

33 Li, H., Zhao, L., Yang, Z., Funder, J. W. and Liu, J.-P. (1998) Telomerase is controlled by protein kinase $\mathrm{C} \alpha$ in human breast cancer cells. J. Biol. Chem. 273, 33436-33442

34 Kang, S. S., Kwon, T., Kwon, D. Y. and Do, S. I. (1999) Akt protein kinase enhances human telomerase activity through phosphorylation of telomerase reverse transcriptase subunit. J. Biol. Chem. 274, 13085-13090

35 Ku, W. C., Cheng, A. J. and Wang, T. C. V. (1997) Inhibition of telomerase activity by PKC inhibitors in human nasopharyngeal cancer cells in culture. Biochem. Biophys. Res. Commun. 241, 730-736

36 Cheng, A. J., Tang, R., Wang, J. Y., Chang, J. T. and Wang, T. C. V. (1999) Polymerase chain reaction-based enzyme immunoassay for quantitation of telomerase activity: application to colorectal cancers. Jpn. J. Cancer Res. 90, 280-285

37 Hug, H. and Sarre, T. F. (1993) Protein kinase C isoenzymes: divergence in signal transduction. Biochem. J. 291, 329-343

38 Liu, J.-P. (1999) Studies of the molecular mechanisms in the regulation of telomerase activity. FASEB J. 13, 2091-2104 